\title{
DYNAMICS OF TUNISIAN POLYGAMY LAW IN GENDER PERSPECTIVE
}

\author{
Ayyus Sahidatul Chusnayaini \\ Fakultas Syari'ah UIN Maulana Malik Ibrahim Malang \\ email: Hime funkhow@yahoo.com
}

\begin{abstract}
Abtract:
This research aims to answer the problem of dynamics of Tunisian polygamy law in gender perspective. The method was used in this study was the type of normative research with collaboration of the historical, statute and conceptual approach.

The results of determines that the dynamics of polygamy law is a great revolution in Tunisia. There are several factors that influence the dynamics: understanding of religion; secular ideology; socio-cultural; political; and education. This dynamics can be seen from the third period of legal development, namely: a) the period of preindependence b) The period after independence c) the period of the revolution (nowadays). There are some issue about the discourse of law legalizing on banning polygamy law in Tunisia. The dynamics of polygamy law that occurred in the period after independence indicates a progression of the effort from Tunisian State to protect the rights of women.

Penelitian ini bertujuan untuk menjawab masalah dinamisasi hukum poligami di Tunisia menurut gender. Penelitian ini menggunakan metode pendekatan penelitian normatif dengan mengolaborasikan sejarah, undang-undang dan konsep.

Hasil penelitian dinamika menunjukan sebuah revolusi yang besar di Tunisia. Diantara faktor-faktor yang mempengaruhi dinamika tersebut adalah: pemahaman agama; idiologi sekuler; susio-kultural; politik; dan pendidikan. Dinamika ini dapat dilihat dari 3 periode perkembangannya, yang disebut: a) periode sebelum independen; b) periode setelah independen; dan c) periode revolusi (sekarang). Ada beberapa persoalan tentang wacana hukum yang melegalkan larangan poligami di Tunisia. Dinamika hukum poligami yang terjadi setelah kemerdekaan menunjukan usaha negara Tunisia untuk meningkatkan perlindungan terhadap hak-hak wanita.
\end{abstract}

Keywords: Dynamics, Gender, Polygamy Law, Tunisia

One of phenomenon were risen in the Muslim world in the $20^{\text {th }}$ century was the existence of the family law reforms which is predominantly occurred in Muslim countries. ${ }^{1}$ Family law is a basic of Islamic Shariah and characteristic of the structure and ethos of Islamic civilization for centuries. In addition the Islamic Family Law is an area where

\footnotetext{
${ }^{1}$ Atho’Mudzhar, “Hukum Keluarga di Dunia Islam Modern Studi Perbandingan dan Keberanjakan UU Modern dari Kitab-Kitab Fikih" (Jakarta: Ciputat Press, 2003), p. 10
}

Islamic law is actually applied in almost every country in the Islamic world. ${ }^{2}$

The reform of family law was firstly performed by Turkey when issuing the Ottoman Law of Family Rights (Qanun alHuquq qarar al-'Á'ilah al-' Usmâniyyah) in 1917. ${ }^{3}$ After that it was followed by Lebanon

\footnotetext{
${ }^{2}$ J.N.D. Anderson, Hukum Islam Di Dunia Moderen, Alih Bahasa Machnun Husain, Cet. I (Yogyakarta: Tiara Wacana, 1994), p. 100.

${ }^{3}$ Tahir Mahmood, Family Law Reform in the Muslim World (Bombay: N. M. TRIPATHI PVT. LTD,1972), p. 17
} 
in 1919, Jordan in 1951, and the Syrians in 1953, including Tunisia in $1957 .{ }^{4}$

Tunisia is an Islamic country which has the official name of the Republic of Tunisia the capital is Tunis, located in North Africa. The country is bordered by Algeria in the west, the north and eastern Mediteranian, with Libyan in southeastern. The country's population numbered 10 million people are concentrated in the north, $98 \%$ of population are Muslim. ${ }^{5}$ The country got independence in 1956 with Habib Bourguiba as the first president ${ }^{6}$.

Polygamy law which is applied in Tunisia is far different from the modern family law in some Islamic Countries in the world. As we know, polygamy so far performed widely among Muslims based on the verses of the Qur'an has allowed explicitly for Muslims to practice polygamy. It has been established in the QS An-Nisa: ${ }^{7}$

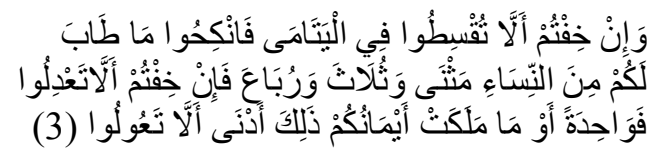

"And if you fear that you will not deal justly with the orphan women, then marry those that please you of (other) women, two or three or four. But if you fear that you will not be just, then (marry only) one or those your right hand possesses. That is more suitable that you may not incline (to injustice). (Q.S an-Nisa':3)

Polygamy marriage was often associated with gender issues, which is one form of inequality between men and women. The study of gender is not just an effort to understand women or men separately, but how to put both within the context of a social system in which both an integral part in it. It also positions between men and women equally

\footnotetext{
${ }^{4}$ Ibid., p. 73 and 93

${ }^{5}$ Jumlah Penduduk (Seluruhnya), http://statistik.ptkpt.net/_a.php? a=penduduk_usi a\&info1 $=3$, diakses pada tanggal 16 Desember 2013

${ }^{6}$ The New Encyclopedia Britannica, under article Tunisia.(USA: Encyclopedia Britannica Inc, 1979)

${ }^{7}$ Q.S an-Nisa' (4): 2-3
}

in access, participation, control and benefits in life activities both within the family, community, and nation and state. ${ }^{8}$

The prohibition of polygamy in Tunisia above, actually that Tunisia wants to raise and protect the dignity and rights of Tunisian women. The banning of polygamy received condemnation from the community try to legalize it back with various reasons because contradict with shariah principle. From this issue, the author wants to make research about dynamics of Tunisian polygamy law in gender perspective.

Based on the background of research above the author can conclude some of purpose of her research are: 1) To describe the dynamics of polygamy laws in Tunisia 2) To analyze the dynamics of Tunisian polygamy laws in gender perspective.

\section{Historical Background of Islamic Family Law Reform in Tunisia}

Tunisia is a Moslem Arab country located in the Maghreb region. In 1956, Tunisia has attained the status of an independent nation and later, in 1957, became a Republic. Under the Constitution of Tunisia Islam is the state region. ${ }^{9}$ Tunisia also has the official name is the Republic of Tunisia with its capital in Tunis, North Africa. The population reached approximately 10.732 .900 people. ${ }^{10}$

Maliki's scholar has a big role in the initiation of law enforcement officially recognized after Tunisian State was formed. In the past, this country was a kingdom Charthage in $814 \mathrm{BC}$. Then the Kingdom Charthage got the Islamic influence from companion of the Prophet named Uqbah bin Nafi ra. As a result of the dynasty changing who leads the Islam, then appeared several dynasties. Almost all of them, they claimed descent from the Turks that

\footnotetext{
${ }^{8}$ Mufidah Ch, Psikologi Keluarga Islam Berwawasan Gender (Malang: UIN-Malang Press, 2008), p.18.

${ }^{9}$ The Constitution of Tunisia, 1959, article 1, and see Tahir Mahmood, Muslim Family Law Reform, p. 99

Statistik Penduduk (seluruhnya), http://statistik.ptkpt.net/_a.php?_a=penduduk_usi a\&info1=3, was accessed on16 March 2014.
} 
bring the Hanafi scholar to Tunisia. ${ }^{11}$ Finally after dominated by the Ottoman Empire and the Turkish government adopted the Hanafi officially, then Hanafi was also influence in Tunisia.

In 1883, Tunisia became French Protectorate by La Marsa Convention. ${ }^{12}$ The arrival of the French colonization began early $16^{\text {th }}$ century. In 1957, Tunisia became independent. The first president is Habib Bourguiba.

In the late forties, some prominent Tunisian jurist thought that by a fusion of the Maliki and Hanafi schools of Islamic law a new code of personal status could be envolved in conformity with the changing social conditions of the country. A group of jurists prepared a comparative account of the law under the two schools and published it under the title Laihat Majallat al-Ahkam alSyar'iyyah (Draft Law Islamic Law). Later, the government set up a committee under the supervision by the Shaikh of Islam of the country, Muhammad al-Ja'it, to officially draft a code. Shaikh of the Zaytunah University, Tahir bin' Ashur also participated in the committee's deliberations. The committee submitted to the government the draft of the code of personal status. It was eventually encated under the title of Majallat al-Ahwal alSyakhsiyyah (Code of Personal Statutes) $1956 .{ }^{13}$

Majallat itself consist of marriage legal materials, divorce, and child take care, they have far differentiations from the classical Islamic legal provisions previously (school of Maliki and Hanafi). In further developments, Majallat or the Law Code of Personal Statutes of 1956 has undergone several changes, additions, and further modified through amendments the Act until 1981. The Act consists of 170 chapters were written in 10

\footnotetext{
11،"Mengetahui Sejarah Tunisia", http://www.bimbie.com/sejarah-negaratunisia.htm, was acsessed on January of 12, 2014.

${ }^{12}$ John P. Entelis, "Tunisa" in Jhon L. Esposito dkk. (ed)"The Oxford Encyclopedia of The Modern World,(New York: Oxford University Press, 1995), IV, p. 236.

${ }^{13}$ Ibid., p. 152.
}

volumes which are considered comprehensive enough. This law has undergone seven amendements during the period 1958-1966, through Law no. 70/1958, 77/1959, 41/1962, $1 / 1964,17 / 1964,49 / 1966$, and the last time the Act was amended in 1981 (Law no. 7/1981), ${ }^{14}$ which introduced some important modifications of previous legislation. Although they have implemented based on the Maliki madzhab generally, but this law is not close possible that incorporate some of the principles come from schools of other Islamic legal. ${ }^{15}$ In the history of family law reform description and codification of Tunisia above, there are a lot of reasons the creation and application of new Tunisian law, namely: ${ }^{16}$ 1) Avoiding conflict between the Hanafi and Maliki school of thinkers; 2) Unification of the court becomes national courts, so there is no longer difference between religious court and state court; 3) Establish a modern legislation, as a reference of the judges; 4) Unify the view of society as a whole as a result of the differences from the classical schools; 5) Introduce new legislation accordance to the demands of modernity;

Tunisian code applies for all citizens of Tunisia. One of Islamic family law reform in Tunisian State about polygamy is "plurality of wives is prohibited. Any person who being already married and before the marriage is lawfully dissolved, marriage again shall be liable to imprisonment for one year or for a fine of 240.000 malims, or to both, even if the second marriage is in violation of any requirement of this Code". ${ }^{17}$ The Amendment Law of 1964 settled the controversy by including bigamous marriages in the list of invalid (fasid) marriage.

\footnotetext{
${ }^{14}$ Tahir Mahmood, Personal Law, and also see supra note 8. Tahir Mahmood present selection of articles from the Codde and their Enflish translation is based on Government of Tunisia, Majalah al-Ahwal al- Shakhsiyah (Mulhiq alHalat al Madaniyah, al Walayah wa'l-Tabanni)Tunis, 1986.

15 Atho' Mudzhar, Hukum Keluarga di Dunia Islam Modern (Ciputat Press: Jakarta Selatan), p.86

16 J.N.D. Anderson, "The Tunisian Law of Personal Status", in the International and Comparative Law Quarterly, 7 April 1985, p. 262.

${ }^{17}$ See Code of Personal Status 1957 article 18
} 


\section{Polygamy In Islam}

Etymologically, polygamy comes from the Greek, polus or poly meaning is many and gamein or gamos, which means marry or marriage. Linguistically, polygamy means is a marriage that have more of a male or female. ${ }^{18}$ Polygamy can be divided into polygamy and polyandry. While the Dictionary of Popular Science said that polygamy is a marriage between two persons or more, but it tends to mean is marriage one husband with two wives or more, which is usually called polygamy. ${ }^{19}$

In Islam, polygamy limited to four wives. The legal basis for the permissibility of polygamy to four wives is described by Allah: ${ }^{20}$

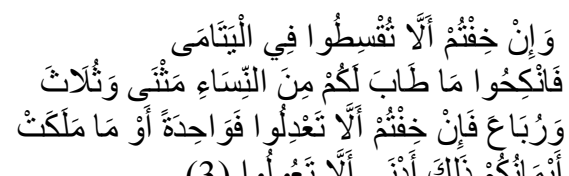

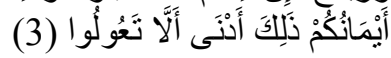

"And if you fear that you will not deal justly with the orphan girls, then marry those that please you of [other] women, two or three or four. But if you fear that you will not be just, then (marry only) one or those your right hand possesses. That is more suitable that you may not incline (to injustice) (Q.S an-Nisa':3) $)^{21}$

\section{History of Polygamy}

In the pre-Islamic period, there is no provision about the number of women who may be married. In the Arabian Peninsula, people have practiced polygamy without limits. When Islam came, the custom of polygamy was not necessarily abolished. However, after the mention of polygamy verse was revealed, the Prophet then do a radical change in accordance with the instructions verses content. First, limit the amount of

\footnotetext{
${ }^{18}$ Dewan Redaksi Ensiklopedi Islam, Ensiklopedi Islam, Jilid 4, (Jakarta: PT. Ichtiar Baru Van Hoeve, 1994), p. 107.

19 Pius A. Partanto dan M. Dahlan al-Barry, Kamus Ilmiah Populer, (Surabaya: Arkola, 1994), p. 606.

${ }^{20}$ Q.S. an-Nisa' (4): 2-3

${ }^{21}$ Qur'an, http://quran.com/4, was accessed on 12 March 2014
}

numbers only up to four wives. In the history of Thabit ibn Qays Another said:

"When I embraced Islam had eight wives. I deliver it to the Prophet and he said:" select from those four people. " similar history of Ghailan ibn Salamah Al-Thaqafi explained that he had ten wives, the Rasul said:" choose four and divorce the other person.

Second, establish strict requirements for polygamy, which should be able to be fair. The requirements set for the permissibility of polygamy was very heavy, and almost certainly no one is able to fulfill it. This means that Islamic polygamy tightened requirements such that men should no longer arbitrarily against their wives as before. Thus, it appears that the practice of polygamy in Islam is very different from the practice of polygamy before.

\section{Contextualization Toward Text Islamic Family Law}

In responding to the problems that continue to develop, the two sources of the Qur'an and the Hadith need intermediaries to convey moral messages and divine truth in a different context with the revelation. This process is often referred to as an interpretation, in which case the relation between text and dialectical context. Contextualization of Islamic family law is a way to seen and understood a text by looking at the outsidelevel of text with not ignore social factors, culture and conditions of the society. In short, the lessons contextualization-law is wisdom behind the text. ${ }^{22}$

\section{The Justice in a Polygamous Marriage}

Definition of justice is difficult to get appropriate definition. In generally, modern scholars tighten permissible of polygamous marriage. Even some of them ban of this marriage, although behind the prohibition is still accompanied by conditions which still gives the possibility to do that. The reason of Modern thinkers prohibit marry with women

\footnotetext{
22 Mufidah Ch (eds), Isu-Isu Gender Kontemporer Dalam Hukum Keluarga (Malang: UIN-Maliki Press), p. 66
} 
more than one or, if they allow it to be followed by various terms that almost could not possibly be met by a husband to do justice to the wives.

The scholars have different opinion about the justice issues that must be owned by a husband who wanted to practice polygamy. Hanafiyah scholar stated that the reference to do justice is the problem clothing, food, and socially, not in a sexual relationship problems. Thus Hanafiyah scholar in the fairness issues that must be implemented by a husband is fair in the matter distribution of the material or the cost of living, ${ }^{23}$ is not about immaterial matter.

In different expressions, Fazlur Rahman said that the ability to have more than one wife is an exception because of certain circumstances. Because of the reality is the permissibility of polygamy rise if the war happen, where many orphans and widows abondaned by parents and her husband. Instead Muhammad Abduh stating that polygamy is forbidden. Polygamy may only be undertaken by a husband in certain cases, such as the inability of a wife to pregnancy or childbirth. ${ }^{24}$

After quoting the word of God in $A n$ Nisa: 3, he notes that Islam permits polygamy but are charged must able to serve fairly. From this condition, according to Abduh can be specified into three conditions, namely: 1) permissibility of polygamy in accordance with the conditions of the demands of the times. 2) requirements can do justice is a condition that is very heavy. 3) a husband who does not carry out the terms demanded separately polygamy, monogamy should do.

For Abduh, polygamy is an act that is forbidden when the purpose is just for fun, but if the reason is because of the demands of the times or emergency, then possible the chances are allowed to do.

\footnotetext{
${ }^{23}$ Rifyal Ka'bah, Hukum Islam di Indonesia, (Jakarta: Yarsi, 1999), p. 32.

${ }^{24}$ Muhammad Imarah, Al-Imam Muhammad Abduh, (AlMujaddid Al-Islam, 1981), p. 24
}

\section{Definition of Gender}

Gender is an inherent in both men and women are socially constructed, cultural or social relationships constructed between women and men are varied and highly dependent on factors of culture, religion, history, and economics. ${ }^{25}$ Wilson $^{26}$ and Elaine Sholwalter quoted Zaitunah $^{27}$ that gender is not just a distinction between men and women's views of the social construction of culture, but with more emphasis on the concept of analysis in understanding and explaining something. So many associations with the word gender justice, equality and so forth which has the sense that it is difficult to be separated. ${ }^{28}$

While understanding the sex of an interpretation or division of two human sexes are biologically determined permanent and universal. Mansour Fakih said, gender is an inherent nature of men and women who are socially and culturally constructed. ${ }^{29}$

\section{Gender Equality in Islam}

The word gender, not exactly found in the Qu'ran, but the word is seen near with the word gender if the reviewed of the role function and relation is the word al rijal and an-Nisa'. The word al-rijalis a plural form of the word rajulun interpreted by men, women opponents. While the word al-Nisa 'is a plural form of al-mar'ah means women who have mature or adult. ${ }^{30}$

\footnotetext{
${ }^{25}$ Sugihastuti and Siti Hariti Sastriyani ,Glosarium Seks \& Gender (Yogyakarta: Carasvati Book: 2007, p. 72.

${ }^{26}$ HT, Wilson, Sex and Gender, Making Cultural Sense of Civilization (Laden: 1998), p.2

${ }^{27}$ Zaitunah Subhan, Rekonstruksi Pemahaman Jender Dalam Islam: Agenda Sosio-Kultural Dan Politik Peran Perempuan (Jakarta: el-Kahfi, 2002), p. 13.

${ }^{28}$ Mufidah Ch, Psikollogi Keluarga Islam Berwawasan Gender (UIN-Malang Press: 2008), p. 2

29 Mansour Fakih, Isue-isue dan Manifestasi Ketidakadilan Gender, dalam Mukhotib MD., (ed.), Menggagas Jurnalisme Sensitif Gender (Yogyakarta: PMII Komisariat IAIN Sunan Kalijaga, 1998), p. 3-4.

${ }^{30}$ Mufidah Ch, Psikologi Keluarga ...,p. 5
} 
The concept of gender equality in Islam has indeed become a part of substantive of the Islamic universal values through revelation (Qur'an and Hadith). Men and women have a position between the equal rights and obligations as a servant of God except faith in front of God. Speaking about the position of women, in this case can be raise one verse from the word of Allah SWT: ${ }^{31}$

"O mankind, indeed We have created you from male and female and made you peoples and tribes that you may know one another. Indeed, the most noble of you in the sight of Allah is the most righteous of you. Indeed, Allah is Knowing and Acquainted.(QS. Al-Hujurat: $13)^{32}$.

\section{The Dynamic of Polygamy Law in Republic} of Tunisia

\section{Pre-Independence Era (before 1956)}

The development of law in the Republic of Tunisia began in the period before independence when the country was still under the influence of the spread of Islam by Uqbah bin Nafi ra Islam was introduced to the public which at that time Tunisia was still a kingdom Charthage having confidence in animism. ${ }^{33}$ At that time Tunisia is still led by a dynasty of kings (the title of Bay).

In 1930 the family law applied in Tunisia is based on Islamic Shari'ah. In the history of Tunisia, since the beginning of Islam was introduced, the majority of the people are Sunni Muslim Tunisia (Malikiyyah). Besides Maliki's school, the influence of Hanafis school then appeared and it started to take effect after the Ottoman empire was dominated formally in Tunisian territory. Consequently the provisions of the laws at that time were

\footnotetext{
${ }^{31}$ Q.S al-Hujurat(49): 13

${ }^{32}$ Qur'an, http://quran.com/49/13, was accessed on 12 March 2014

${ }^{33}$ Tim, ensiklopedia Bangsa dan Negara Jilid 1 ( Jakarta: PT. Grolier Internasional Inc, 2000), p. 88.
}

based on the two schools until the judicial institutions with the two judges. ${ }^{34}$

Dynamically polygamy legal developments which occurred in this state run together with social change in Islamic societies. Provisions of law relating to polygamy, Tunisia has allowed a husband to have a maximum of four wives. This provision based on sound of polygamy verse in Q.S an-Nisa': 3:

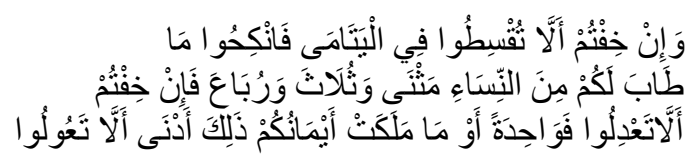

"And if you fear that you will not deal justly with the orphan women, then marry those that please you of (other) women, two or three or four. But if you fear that you will not be just, then (marry only) one or those your right hand possesses. That is more suitable that you may not incline (to injustice). (Q.S an-Nisa':3)

In addition, this is caused by several factors including: a) religion understanding of Tunisian society about Islamic law provision is so simple (taqlid) and Imam Madzhab has great position in society b) men had control over women in social life, patriarchal culture still dominates in Tunisian society to discrimination and inequality between men and women c) emerge The Young Tunisian movement d) did not emerge the new Muslim scientists that concern in Islamic family law.

\section{Period Post Independence of Tunisia (1956- 2011)}

The establishment of law in Tunisia in terms of development of national laws, actually has been going on since 1957, when the Code of Personal Statutes (Republique Tunisienne (مجلة/الأحوالالشخصية) applied. From the history, it can be concluded that the

\footnotetext{
${ }^{34}$ Atho' Muzdhar, Hukum Keluarga Dunia di Dunia Islam Modern Studi Perbandingan dan Keberanjakan UU Modern dari Kitab-Kitab Fikih (Jakarta: Coputat Press, 2003), p.85
} 
current law was influenced by political forces.

Law is more familiarly called as CPS (Code of Personal Statutes) ${ }^{35}$ is seen as a very secular Islamic law. Renewal of the existing legal provisions in the State CPS Tunisia enforced much different from the classical Islamic law in the country that once defined the majority of the Maliki school. Until many critics who claim that the Tunisian family law contrary with some traditional Muslim practices (Islamic Shariah). ${ }^{36}$

If we examine more closely, in fact Islamic marriage law in force in Tunisia, not exit of the regulations established by the Shariah, but modern scientists emphasize to perform a re-interpretation of the texts of Islamic law by looking at the social context is behind asbabun nuzul the verse. ${ }^{37}$ That could form a legal suit the demands of the times.

The enactment of the Code of Personal Statutes of 1957 made a radical change in the interpretation of Islamic law that deals with family and set new terms for further development. Tunisian Islamic family law rules contained in the CPS (Code of Personal Statutes) contains the rule of law more gender responsive.

Finally, through the Code of Personal Statutes 1956 in article 18, President Bourguiba expressly has prohibited the practice of polygamous marriages in Tunisia. Habib Bourguiba is a Tunisian ruler was known western educated, and he has a thought and a willingness pitched westernized. Thus, has emerged a strong assumption about the secularization

\footnotetext{
${ }^{35}$ M.M Charrad, Policy Shift: State, Islam, and Genderin Tunisia, 1930s-1990s, (Summer: Oxford University Press, 1997), p. 294

36 Atho' Mudzhar, Hukum Keluarga Dunia di Dunia Islam Modern Studi Perbandingan dan Keberanjakan UU Modern dari Kitab-Kitab Fikih (Jakarta: Coputat Press, 2003),p. 84.

37 Mufidah Ch (eds), Isu-Isu Gender Kontemporer Dalam Hukum Keluarga (Malang: UIN-Maliki Press), p. 66
}

of Islamic law made by the Tunisian the authorities at the time. Through the Code of Personal Statutes Article 18, which prohibits polygamy in Tunisia, which reads : ${ }^{38}$

"plurality of wives is prohibited. Any person who being already married and before the marriage is lawfully dissolved, marriage again shall be liable to imprisonment for one year or for a fine of 240.000 malims,or to both, even if the second marriage is in violation of any requirement of this Code."

In Article 18 of the Code of Personal Status 1957 above is expressly and officially the Tunisian government established that polygamy is forbidden by imposing sanctions on offenders who marry more than one wife. The criminalization of the practice of polygamy in Tunisia imposed as a form of threat and reward for violators of the code.

Statutes which are banned polygamy gets a variety responses in Tunisia. For an Islamic traditional (conservative) society and a high knowledge of Islamic science, the Act raises some kind of reaction in the form of deep regret toward the government's way of thinking. In addition, in the community affected by the imperialists and culture among women's organizations, the Act's prohibition of polygamy has received a warm welcome, and considered as a forward step and attempt to free the women in Tunisia. ${ }^{39}$

Ban polygamy law cannot be separated from the influence of several factors underlying the enactment into law a ban on polygamy in Tunisia. Here are the factors that influence them: a) secular ideology of Borguiba as the first president and continued by Ben Ali in next period; b) re-interpretation of religion doctrine; c) legal provision of state has been controlled by government; d) modernization era has occurred in Tunisia; e) women got access in public area; $\mathrm{f}$ ) there is education reform in

\footnotetext{
${ }^{38}$ Code of Personal Status article 18

${ }^{39}$ Musthafa As-Siba'y, Wanita di Antara Hukum Islam dan Perundang-Undangan (Cet. 1., Bulan Bintang: Jakarta, 1977), p. 155.
} 
some university; g) unification of legal jurisdiction (between Maliki and Hanafi scholars) become national court.

Tunisia can be considered as a leading example of the post-1956, Renewal more tender based on the declared rights of Muslim countries, through its rulers to ijtihad. And finally Tunisia remove polygamy rights through Article 18 of the Tunisian Code of Personal Law Statutes, $1956,{ }^{40}$ is based on a reinterpretation of Surat an-Nisa verse 3.

\section{Current Era (2011-present)}

In current condition of the legal development issues that occurred in Tunisia is about re-legalize lawsuit of practice polygamy. This issue happened since Arab spring revolution grown up in Tunisia. It is named the Arab Spring because it occurred in the Arabian peninsula and began to look bloom in the spring. ${ }^{41}$

The freedom era that stricken in Tunisia provide an opportunity for the public to begin speak out in public bravely. They began to voice their disappointment with the government's performance so it looks a lot of massive demonstration colored assorted riots, violence and anarchy that made of injuries and died victims. This happen caused by dictatorship of Ben Ali President.

This situation also bring Tunisian conservative speak up to came back in shariah principle, remember the winner of election is an-Nahdah (Islamic party) to replace Ben Ali president. From the result of the election, Islamic conservation communities have demanded to re-

\footnotetext{
${ }^{40}$ Tahir Mahmood, Personal law...., p. 156-157.

${ }^{41}$ Geopolitik Arab Spring: Tunisia dan Suriah, http://angela-n-a-

fisip10.web.unair.ac.id/artikel_detail-49639-

GeoGeo

Geopolitik\%20Arab\%20Spring:\%20Tunisia\%20da

n\%20Suriap.html, was accessed on 13 January 2014
}

amendment all the secular provision, include prohibition of polygamy in family law field. In conservative opinion, prohibition of polygamy cause many spinsters and alleged prostitution and infidelity increased. A national newspaper says that $80 \%$ of husbands and $68 \%$ wives in the city of Tunis claimed to have had a dishonest. ${ }^{42}$ Hence, many of them ask to re-legalize the practice polygamy. Here are the factors that influence them: a) Winnings of election by islamist party (an-Nahdah) b) great freedom era in all areas c) distinction of religious understanding of Islamic doctrine between modernist and islamist in Tunisia.

Adel Elmi, head of the Moderate Tunisian Association for Awareness and Reform Moderate, said that marriage law should be changed with the proposed amendments to the family law of Tunisia (Majallah al ahwal as syakhsiyyah) at that time. Family law set by President Habib Borguiba that is the secular considered the most progressive in the Islamic world at that time, had another negative response from the public. ${ }^{43}$

According of them, he prohibition of polygamy does not bring benefit to Muslims in Tunisia. The opposite happened instead, emerging social issues. For example, infidelity, marriage under the hand (Zawaj 'urfi), the phenomenon of the increasing number of divorces and spinsters.

\section{The Dynamics of Tunisian Polygamy Laws in Gender Perspective}

The study of gender is not just an attempt to understand women or men separately, but how to put in the context of a social system in which both an integral part in it. In Islam, the concept of gender equality in fact has become a substantive part of the universal values of Islam through revelation (Qur'an and Hadith). Men and women have a

\footnotetext{
${ }^{42}$ Dede Permana nugraha, Larangan Poligami Digugat Kembali http://permana.blogspot.com/2013_03_01_archiv e.html, diakses pada tanggal 22 Desember 2013

${ }^{43}$ Muslimdaily.net, Organisasi Islam Minta Tunisia Legalkan Poligami
} 
position and get rights and obligations equal as a slave of Allah except the faith in front of Allah: ${ }^{44 ،} O$ mankind, indeed We have created you from male and female and made you peoples and tribes that you may know one another. Indeed, the most noble of you in the sight of Allah is the most righteous of you. Indeed, Allah is Knowing and Acquainted." (QS. Al-Hujurat: 13)

\section{Period Pre-Independence}

The implementation of polygamy law in Tunisia under the provisions of Islamic law based on the Maliki and Hanbali schools provide a practice of polygamy marriage license at the time. In this case the permissibility of polygamy law decision is based on the interpretation of the text of the Qur'an in Sura an-Nisa 'verse 3:

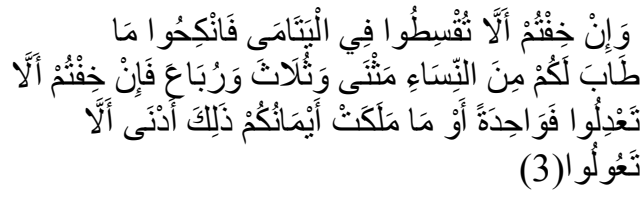

"And if you fear that you will not deal justly with the orphan girls, then marry those that please you of [other] women, two or three or four. But if you fear that you will not be just, then [marry only] one or those your right hand possesses. That is more suitable that you may not incline [to injustice]." (Q.S an-Nisa' $: 3)^{45}$

While the hadith is often raised include:

"From Ibn Umar: that Ghailan ibn Salamah when converted to Islam has 10 wives (who married at the jahiliyah time), the Prophet ordered him to choose four of them as wife. ${ }^{46}$

The legal basis above should be interpreted as well, not only a moral

\footnotetext{
${ }^{44}$ Q.S al-Hujurat(49): 13

${ }^{45}$ Qur'an, http://quran.com/4/3, was accessed on 13th of March 2014

46 at-Tirmidzi, Sunan at-Tirmidzi, juz II (Dar al-Fikr: Beirut, 1994), p. 368.
}

imperative, but also it is a precedent condition for polygamy law, in the sense that no one can be allowed a second marriage except until proven can apply the same (egalitarian) where the wives are treated fairly. But look at the modern condition, social and economic fairness seems to be a thing impossible then polygamy Tunisian law briefly declared that polygamy is forbidden.

In the gender perspective, it does not talk about permission and prohibit polygamy practice, but talk about gender equality. Marital problem of polygamy is a form of gender inequality and injustice. Indicators of gender equality in polygamous marriages have been possible. Moreover, the cultural life of the patriarchal family system emerged in Tunisia. ${ }^{47}$

The assumption of polygamy show the position of men is higher than women that would cause a negative impact on women. Indications of subordination form of women would hamper of participation access, control, particularly in relation to decision-making role. ${ }^{48}$ The Subordination in a polygamous marriage would lead to the position of wives in the household becomes part of her husband's life. Stereotype image of women as weak human, emotional, irresponsible, and dependent on men consider fair for a wife to accept unfavorable treatment from her husband, is vulnerable to get domestic violence. On the one hand, generally wives do not have the good power to put herself equal with her husband position, on the other hand the psychologically wife getting bigger dependence on the husband.

Similarly, marginalization occurs in life of the household as a result of the subordination of women in polygamous marriages. Marginalization forms that are appear for example in regulating the

\footnotetext{
47 M.M. Charrad, Policy Shifts: State, Islam, and Genderin Tunisia, 1930s-1990s, (Summer: Oxford University Press, 1997), p. 290

48 Mufidah Ch, Psikologi Islam Berwawasan gender (Malang: UIN Press, 2008), p. 15.
} 
economy and utilization of resources in the household. Double burden can happen to wives who do not get a decent living from her husband, and conversely, in the context of polygamous marriage, the husband had to fight even harder to complete all the needs of his wives and his children. So there would be a double workload is may be disproportionate because of the many needs that must be completed.

In terms of the ability to do justice in a polygamous marriage is indefinite guarantee to be accounted. Fairness in the provision of material need may be fulfilled, but immaterial need also be a needed for a wife. In this case, there are many polygamous husbands who cannot bring about justice.

\section{Period after Independence}

In the period after independence, the dynamics of polygamy law is starting to show a very radical change. Polygamy is prohibited by Article 18 CPS 1957 which states:

"plurality of wives is prohibited. Any person who being already married and before the marriage is lawfully dissolved, marriage again shall be liable to imprisonment for one year or for a fine of 240.000 malims,or to both, even if the second marriage is in violation of any requirement of this Code. “

The basic of prohibition polygamy that was used by Government of Tunisia, according to John L. Esposito stated that polygamy as slavery, like an institution that is unacceptable majority of mankind everywhere forever. Polygamy is allowed only during development or transition Muslims era, but was forbidden during development or civilized society. Additionally the requirement of polygamy permit contained in Qur'an namely able to do justice to the wife, while the historical fact has proved that the Prophet able to do justice for his wives only. ${ }^{49}$ In addition, the ideal of the Qur'an about marriage is actually monogamous.

Here, according to Esposito, adding that Muhammad Abduh views on polygamy verses also to be a reference of the Tunisian government in establishing banning polygamy law. According to Abduh, the Qur'an gave permission for a man to have wives more than one has been seriously limited by the Qur'an itself. Thus, the Qur'an is the ideal of monogamy. Moreover, the proposed terms, so that husbands do justice to his wives is a condition that is very difficult, even impossible for realized it fully. ${ }^{50}$

In Tafsir al-Manar Muhammad Abduh also explained that polygamous households with more than one wife with a husband, forever atmosphere will not calm and cannot be implemented any rules on it. Thus, polygamy excess propagated from the individuals into houses and from houses throughout the nation. ${ }^{51}$ The impact of polygamy spread the wives of polygamy, his children, their parents, and their families to promote hostility and hateful each other.

In this case, the reformers Islamic thinkers also contribute in prohibition polygamy law in Tunisia. As presented by the emancipation of women movement in Tunisia, Tahir al Hadad (1899-1935), in his very popular book in Tunis is Imroatuna fi alShari'ah wa al-mujtama'. Tahir Hadad said that polygamy is a form of ugliness contained in the previous Arabs (Sayyiah Min Sayyiat al-Jahiliyah alUla). Hadad describe the phenomenon of Arab men at the time, some people usually married women, even unlimited.

\footnotetext{
${ }^{49}$ Norman Anderson, Law Reform in the Muslim World (London: The Athlone Press, 1976), p. 63.

${ }^{50}$ Khoiruddin Nasution, Riba dan Poligami, (Yogyakarta: Pustaka Pelajar, 1996), p. 84

${ }^{51}$ Musthafa As-Siba'y, Wanita di Antara Hukum Islam dan Perundang-Undangan, (Cet. I; Bulan Bintang: Jakarta, 1977), p.149.
} 
The wife was got unfairly and arbitrarily treatment. Polygamy has no basis in Islam, actually Islam intend to eradicate polygamy. Haddad also considers that polygamy is not in line with the maqasid of marriage itself, which realize the sakinah, mawaddah wa rahmah family to every couple. Those three things would be realized if husband pour affection for one wife only. ${ }^{52}$

Theologically, Islam considers that polygamy is a contextual concept that is followed by a very heavy qualification, namely justice. After the touched on polygamy verse was revealed, then the Prophet do a radical change in accordance with the directions of the verses content. A fundamental change did by the Prophet related with two things. The first is the number of wife from an unlimited number be limited to only four. Secondly, in terms of polygamy, that should be able to be fair. Thus, essence of the verses emphasizes a warning to mankind in order to avoid unfair or discriminatory. Remembering the difficulty to be fair that contain in the next verse an-Nisa 'verses 129 , actually the verse contain the threat of polygamy than allow it. ${ }^{53}$ In this case, that only Prophet Mohammad as the exception that proved be able to do justice to his wives. The following verses Q.S an-Nisa 'verses 129 decree:

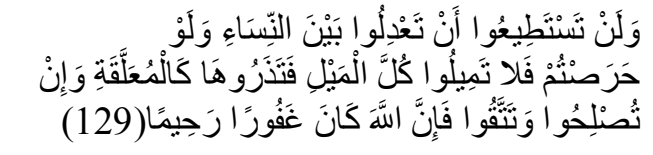

"And you will never be able to be equal [in feeling] between wives, even if you should strive [to do so]. So do not incline completely [toward one] and leave another hanging. And if you amend [your affairs] and fear Allah then indeed, Allah is ever forgiving and Merciful." (Q.S an-Nisa':129)

The prophet practice polygamy, but he does not bless his son in law to practice polygamy. It is associated with the fairness that should be done in polygamy, which not everyone will be able to do so, including Ali ibn Abi Talib, when he has tested of his faith, but as a human he would not be able to do justice as did the Messenger of Allah as Allah say in surah an-Nisa' (4):129.

Thus, polygamy can be concluded extremely that Islam wants to slowly remove the tradition of polygamy, although not directly contained in the Qur'an and Sunnah. It can be affirmed with a graphic illustration as follows:

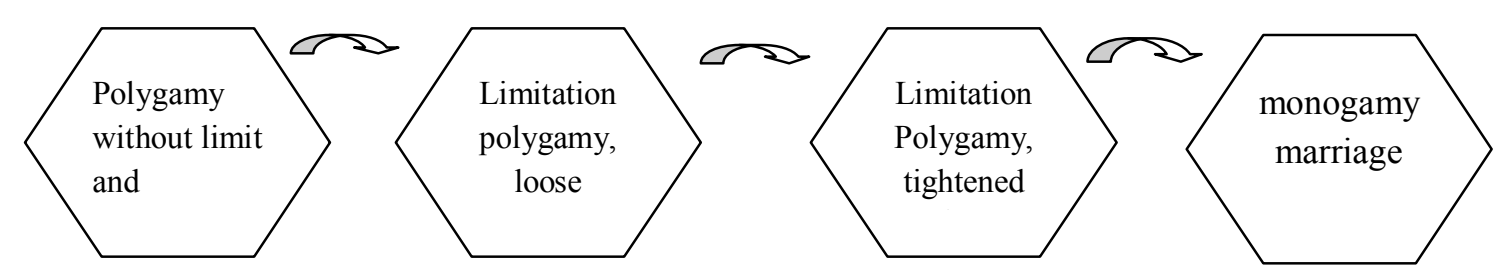

\footnotetext{
${ }^{52}$ Dede Permana nugraha, Larangan Poligami Digugat Kembali, http://anNisa'permana.blogspot.com/2013 $03 \quad 01$ archive .html, was accesswd on 22 December $20 \overline{13}$.

${ }^{53}$ Musda Mulia, Pandangan Islam Tentang Poligami, (Cet.1, Jakarta: Lembaga Kajian Agama dan Gender, 1999) p. 49.
} 
In the context of marriage that is equality and equity of gender based on several indicators namely the husband and wife both have access in domestic life, get a balance roles in the household, accept the same the authority and responsibility, get the same benefits in the household. In the gender perspective, monogamous marriage form becomes the one option that facilitates to build sakinah, mawaddah wa rahmah household as well as healthy physically and spiritual for husband and wife. ${ }^{54}$

The relation between husband and wife in a monogamous marriage is based on the principle of mu'asyarah bi al-ma 'ruf can be implemented. Marital monogamy can build relationships in a positive interaction pattern, in harmony with a peaceful mood, which is also characterized by a balance of rights and obligations between them. Sakinah mawaddah wa Rahmah family can be realized as an ideal family. ${ }^{55}$

Law is the most formal manifestation of government policy. Without legal protection, there is no helper or refuge for women. Legal reforms needed to achieve gender equity that can be viewed from the perspective that eliminates the dichotomy between public and domestic field, so that produce the regulation (code) more fair for the husband and wife. ${ }^{56}$

If we observe, the law of banning polygamy in Tunisia is not only stop ban the practice of polygamous marriages, but also give punish for the person who is break them. Even in 1964, the Tunisian government is not only to punish of polygamist, but polygamy include as a marriage invalid. ${ }^{57}$

In the Kamus Besar Bahasa Indonesia book, criminalization is means the process of showing of behavior that

\footnotetext{
${ }^{54}$ Mufidah Ch, Psikologi Keluarga ..., p. 238

${ }_{55}^{55}$ Mufidah Ch, Psikologi Keluarga ..., p. 178

56 Shelby Quast, Justice Reform and Gender, terj. Catherine Muir (Jakarta: IDSPS Press, 2008), p. 5

${ }^{57}$ Tahir Mahmood, Muslim Family Law Reform, p. 101, see also article 21 as amended by law no. 1 of 1964
}

previous unregarded as a criminal incident, but later classified as a criminal act by the public. ${ }^{58}$ Thus the criminalization of polygamy here understood as a gesture to categorize practices / actions polygamy as a criminal offense (crime), which is threatened to certain criminal forms, both criminal imprisonment and criminal fine. ${ }^{59}$

Abolition of this polygamy is implemented with the aim to close the practice of polygamy. In article 18 CPS Tunisian government explicitly prohibits polygamy and imposed a penalty of violating the rules: ${ }^{60}$

"plurality of wives is prohibited. Any person who being already married and before the marriage is lawfully dissolved, marriage again shall be liable to imprisonment for one year or for a fine of 240.000 malims, or to both, even if the second marriage is in violation of any requirement of this Code."

From the article above, we can know that the Tunisian State enforces the provisions marriage laws consistent with the principles espoused a monogamous marriage. Polygamy banning based on Code of Personal Status 1957 in article 18. In this provision, consist of :a) banning polygamy absolutely b) there is no requirement as an exception $\mathrm{d}$. criminalization of polygamy practice c) polygamy is one of invalid marriage in gender perspective this provision is one of advance product of Islamic family law.

\section{Current Situation}

The disappointment that comes as a response to Tunisian conservative society eventually led to the issue of amendment law about prohibition of polygamy which was invite controversy in Tunisia. This situation

\footnotetext{
58 Tim Depdikbud, Kamus Besar Bahasa Indonesia, Edisi III, (Balai Pustaka: Jakarta, 2001), p. 600.

59 Andi Hamzah, Asas-Asas Hukum Pidana, (Rineka Cipta: Jakarta, 1991), p. 5

60 Tahir Mahmood, Personal Law in Islamic Country (New Delhi: Academy of Law and Religion, 1987), p. 156.
} 
became a discourse during the Arab spring accident on year 2011 until now. Moderate Islamic country that brought the concept of gender to defend women's rights has been included in the provisions of law in force in Tunisia since 1957. The moderate Muslims who understand that the permissibility of polygamy in Islam associated with illat / reason / specific context agree with the banning polygamy law for the context of Tunisia. Pros and cons indeed continue between agree on amendment and disagree about it. However, the provisions of the law, conservative Islamic circles consider that the prohibition polygamy in the CPS is contrary with the provisions of Islamic law and not make the fate of Tunisian women better than women in other Arab countries. ${ }^{61}$ They feel there is shift of the gender concept that protected the women's right. The prohibition of polygamy in Tunisia bring the negative impact for women lately, because there is information mentioned that occur illegal marriage (unregistered marriage), prostitution, etc.

In a gender perspective, polygamy debate that surfaced in the community over on the extent to which of the impact will be devastating to the future of women and gives women the freedom to optimize their utility to men in a love with many women. It is given that the arguments used scholars' modern is characteristic that tends to make it difficult the requirements of justice in the present and realize the desire a monogamous marriage and the assurance of a future generation. On the other hand, the argument militant Islamic conservative, tend to simplify the problem by using religious arguments to legalize polygamy.

Actually there is no duty to ban of polygamy absolutely to protect women's rights in family law field. The discourse that still happen about re-legalize of banning polygamy among islamist and modernist community in Tunisia, will be better if there is compromise

\footnotetext{
${ }^{61}$ Dede Permana Nugraha, "Larangan Poligami Digugat Kembali", http://anNisa'permana.blogspot.com/2013 0301 archive html, was accessed on 22December 2013
}

and tolerance to hold the legal provision that still occur in Tunisia.

\section{Conclusion}

Based on what has been described throughly and detail related to this research, further researcher will provide conclusions as the final result:

The dynamics of polygamy law shows a revolutionary development in Tunisia. There are several factors that influence the dynamics, ie understanding of religion, secular ideologies, socio-cultural, political, and education. This dynamic can be seen from the third period of the development of law, namely: a) At the beginning of the pre-independence period, the law of polygamy is permissible for a husband. b) the post-independence period there is legal prohibition of polygamy through the Code of Personal Status aricle 18. Violation of this provision gets 1-year prison sentence and / fine of 240,000 malim. c) While the recent developments, there is the issue of law suit toward ban on polygamy to reamendment.

In gender perspective, the dynamics of polygamy in Tunisia that occurred in the period after independence shows a forward step in the Tunisian State as an effort to protect the rights of women to carry out reinterpretation of the social context of the verses polygamy with stating that polygamy is prohibited in the State of Tunisia. But in the next period until the author has completed her research, there is the issue about the lawsuit of banning polygamy to legalized in Tunisia. Until now this issue became a legal discourse in Tunisia.

\section{Suggestion}

Actually polygamy is a marriage which is not recommended nor forbidden in Islam. Legal prohibition of polygamy in Tunisia is a strategic move selected by Tunisian government to protect the rights of women from discrimination and injustice. 
The scope of this research is focused on polygamous marriages legal provisions contained in the legislation of the Personal Status Code only. How far the Act became effective in the society and how is the implementation in the community, the the author herself is still not clearly know. Researcher has big hope that in the future there is research that discusses the dynamics of polygamous marriage law in Tunisia with different focus problems. So it can be add the Islamic sciencein the future.

\section{REFERENCES}

\section{Book, Research or Journal:}

Al-Jashash. Ahkam al-Qur'an. Beirut: Dar al-Kitab al-Islamiyah, tt.

Anderson, J.N.D. Hukum Islam Di Dunia Moderen. Terj. Machnun Husain, Cet. I Yogyakarta: Tiara Wacana, 1994.

Anderson, Norman. Law Reform in the Muslim World. London: The Athlone Press, 1976.

As-Siba'y, Musthafa. Wanita di Antara Hukum Islam dan Perundang-Undangan. Cet 1. Bulan Bintang: Jakarta, 1977

As-Syaibaniy, Ahmad bin Hanbal Abu Abdillah, Musnad Ahmad. Juz 2. Mesir: Muasasah, tt.

at-Tirmidzi. Sunan at-Tirmidzi. juz II. Dar al-Fikr: Beirut, 1994.

Ch, Mufidah (eds). Isu-Isu Gender Kontemporer Dalam Hukum Keluarga. Malang: UIN-Maliki Press.

Ch, Mufidah. Psikologi Keluarga Islam Berwawasan Gender. UIN-Malang Press:2008.

Charrad, M.M. Policy Shifts: State, Islam, and Genderin Tunisia, 1930s- 1990s. Summer: Oxford University Press, 1997.

Charrad, M. Tunisia at The Forefront of The Arab World, dalam Fatima Sadiqi dan Moha Ennaji (ed.) et.al., "Women in The
Middle East and Nort Africa (Agent of Change)". USA: Routledge, 2011.

Departemen Pendidikan dan

Kebudayaan. Kamus Besar Bahasa Indonesia. Edition 2. Jakarta: Balai Pustaka, 1996.

Dewan Redaksi Ensiklopedi Islam. Ensiklopedi Islam, Volume 4. Jakarta: PT. Ichtiar Baru Van Hoeve, 1994.

Entelis, John P. Tunisa dalam Jhon L. Esposito dkk. (ed)" The Oxford Encyclopedia of The Modern World. New York: Oxford University Press, 1995.

Fahmi, Anshori. Siapa Bilang Poligami itu Sunnah?. Bandung: Pustaka Iman, 2007.

Hamzah, Andi. Asas-Asas Hukum Pidana. Rineka Cipta: Jakarta, 1991.

Handayani, Trisakti dan Sugiarti, Konsep dan Tekhnik Penelitian Gender. Malang: UMM press, 2006.

Imarah, Muhammad. Al-Imam Muhammad Abduh. Al-Mujaddid AlIslam, 1981.

Jones, Christina. Women Under Islam (Gender, Justice and The Politics od Islamic Law. New York: I.B Tauris, 2011.

Ka'bah, Rifyal. Hukum Islam di Indonesia. Jakarta: Yarsi, 1999.

Mahmood, Tahir . Family Law Reform in the Muslim World. Bombay: N. M. TRIPATHI PVT. LTD, 1972.

Mahmood, Tahir. Personal law in Islamic Country. New Delhi: Academy of Law and Religion, 1987.

Mulia, Siti Musdah, Dr., MA., APU., Pandangan Islam Tentang Poligami, Jakarta: Lembaga Kajian Agama dan Genderh. Cet 1. 1999.

Muzdhar, Atho'. Hukum Keluarga Dunia di Dunia Islam Modern Studi Perbandingan dan Keberanjakan UU 
Modern dari Kitab-Kitab Fikih. Jakarta: Coputat Press, 2003

Nasution , Khoiruddin. Riba dan Poligami. Yogyakarta: Pustaka Pelajar, 1996.

Partanto, Pius A. dan M. Dahlan alBarry. Kamus Ilmiah Populer. Surabaya: Arkola, 1994.

Quast, Shelby. Justice Reform and Gender, terj. Catherine Muir. Jakarta: IDSPS Press, 2008.

Ridha, Muhammad Rasyid. Tafsir AlManar. juz 4. Kairo: Al-Manar, 1367.

Simon, Reeva S. dkk. (Ed.). Encyclopedia of Modern Middle East. New York: USA, 1996.

Subhan, Zaitunah. Rekonstruksi Pemahaman Jender Dalam Islam:Agenda Sosio-Kultural Dan Politik Peran Perempuan. Jakarta: el-Kahfi, 2002.

Sugihastuti dan Siti Hariti Sastriyani. Glosarium Seks \& Gender. Yogyakarta: Carasvati Book: 2007.

Syihab, Quraish. Wawasan Al-Qur'an: Tafsir Maudhu'i atas Perbagai Persoalan Umat. Bandung: Mizan, 1996.

Tim Depdikbud, Kamus Besar Bahasa Indonesia, Edition 3. Balai Pustaka: Jakarta, 2001.

Tim. Ensiklopedia Bangsa dan Negara. Volume 1. Jakarta: PT. Grolier Internasional Inc, 2000.
Tunisian Code of Personal Status 1957

Wilson, HT. Sex and Gender, Making Cultural Sense of Civilization. Laden: 1998.

Zaki Saleh, Muhammad . "Trend Kriminalisasi Dalam Hukum Keluarga Di Negara-Negara Muslim”. Makalah . Presented on forum "Annual Conference Kajian Islam Lembang”. Bandung, 2006.

\section{Website}

Dede Permana nugraha, Larangan http://permana.blogspot.com/2013 03

01 archive.html, was accessed on December $22^{\overline{\mathrm{th}}} 2013$

Geopolitik Arab Spring: Tunisia dan Suriah, $\quad$ http://angela-n-afisip10.web.unair.ac.id/artikel detail-49639GeoGeo

Geopolitik\%20Arab\%20Spring:\%20Tunisia\%2 0dan $\% 20$ Suriah.html, was accessed on January $13^{\text {th }} 2014$

Jumlah Penduduk (Seluruhnya), http://statistik.ptkpt.net/_a.php? a=pen duduk usia\&info $1=3$, was accessed on December $16^{\text {th }} 2013$

Mengetahui Sejarah Tunisia, http://www.bimbie.com/sejarah-negaratunisia.htm, was accessed on January $12^{\text {th }}$, 2014

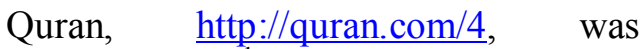
accessed on March $12^{\text {th }} 2014$ 